\title{
The church, food culture, and ecotheology: An ongoing church effort in reducing bushmeat eating in Minahasa, Indonesia
}

\author{
Alva Supit ${ }^{\mathrm{a}, \mathrm{d}}$, Agusteivie Telew ${ }^{\mathrm{b}, \mathrm{d}}$, Nancy Bawiling ${ }^{\mathrm{c}, \mathrm{d}}$ \\ a MD, MSc, PGDipClinRes, PhD student in Biomedical Sciences, City University of Hong Kong, Hong Kong \\ ${ }^{\mathrm{b}} \mathrm{MD}, \mathrm{MSC}$ \\ ${ }^{c} \mathrm{MD}, \mathrm{MSc}$, Budi Setia Hospital Langowan, Minahasa, Indonesia \\ ${ }^{d}$ Public Health Department, Manado State University, Indonesia
}

\begin{abstract}
Minahasa is a Christian-majority region in the Muslim-majority country of Indonesia. Most of the Minahasan people are meat consumers, with an increased consumption rate during festive seasons. Unfortunately, during these seasons, the consumption of non-cattle animals such as wild animals also increases. This eating style was reported to be related to the high prevalence of metabolic diseases in this area. In this paper, we report the effort of the largest church organization in Minahasa to promote healthy eating habits among its congregation, which comprises the majority of the society of the region. More recently, the church has also been incorporating the values of wild animal conservation in its programs in collaboration with a local non-government organization. This ongoing unique phenomenon might serve as a unique example of how a church organization can be involved in public and planetary health as a part of its mission to preach the gospel to every creature.
\end{abstract}

Key Words: ecotheology, Minahasa, wild animals, eating habits, COVID-19

\section{Introduction}

Minahasa is a district region in the northern peninsula of Sulawesi Island, Indonesia. Thanks to the efforts of the Netherlands Missionary Society (Nederlandsch Zendelinggenootschap) ministryamong others - in the $19^{\text {th }}$ century, Minahasa had become a Christian-majority area in the Muslimmajority country of Indonesia.
Currently, there are on average 4.13 church buildings in every Minahasan village from various denominations (Table 1). The largest denomination is the Minahasa Evangelical Christian Church (Gereja Masehi Injili di Minahasa, GMIM), possessing 998 out of 3,586 Protestant church buildings/sites in Minahasa.

July 2021. Christian Journal for Global Health 8(1) 
Table 1. The descriptive statistics of churches in Minahasa compared to the Christian and total population and the number of villages

\begin{tabular}{lcccccc}
\hline Districts & $\begin{array}{c}\text { Population (all } \\
\text { religions) }\end{array}$ & $\begin{array}{c}\text { Protestant } \\
\text { population }\end{array}$ & $\begin{array}{c}\text { Catholic } \\
\text { population }\end{array}$ & $\begin{array}{c}\text { Number of } \\
\text { villages }\end{array}$ & $\begin{array}{c}\text { Protestant } \\
\text { Churches }\end{array}$ & $\begin{array}{c}\text { Catholic } \\
\text { Churches }\end{array}$ \\
\hline Minahasa, central & 347,290 & 290,447 & 27,486 & 270 & 1,016 & 69 \\
South Minahasa & 236,463 & 214,010 & 7,671 & 178 & 514 & 22 \\
North Minahasa & 268,935 & 209,983 & 20,784 & 131 & 478 & 51 \\
Southeast Minahasa & 116,323 & 95,527 & 1,424 & 144 & 306 & 14 \\
Manado City & 451,916 & 306,262 & 27,211 & 87 & 717 & 28 \\
Bitung City & 225,134 & 95,035 & 7,068 & 69 & 452 & 23 \\
\hline Tomohon City & 100,587 & 72,931 & 23,147 & 44 & 103 & 24 \\
\hline Total & $1,702,706$ & $1,284,195$ & 114,791 & 923 & 3,586 & 231 \\
\hline
\end{tabular}

Note: By Indonesian law, Protestant and Catholic are separated into two different religions.

Data source: Ministry of Religious Affairs ${ }^{1}$, North Sulawesi Statistic Bureau ${ }^{2}$

Food is a marker of social status in various civilizations around the world, including Minahasa. ${ }^{3}$ While the Muslim-majority Indonesian people have a restricted meat diet, Minahasan people have been known to eat almost all animals, which can be partially attributed to their non-food-restricting belief in Christianity. Local phrases circulating among Minahasans state that, "Even the devil, after cooked in chili, is our food," as well as "If Adam and Eve were Minahasans, humans would never need to fall into sin because they would eat the snake instead of the forbidden fruit." These jests were not invented by Minahasans, as people from other areas have also claimed these jokes as their own. However, Minahasan people are proud of being the subject of these, at least when chatting among themselves.

It is not common for a Protestant church organization to intervene in what its congregation should or should not eat. ${ }^{4}$ However, in the last few decades, when the protections to endangered animals have been reinforced by the Indonesian law, the church has also been called upon to support the government efforts. It has revived its ecotheological function, as stated by the Edenic charge to humans: to work the earth and take care of it-which also means to keep, maintain, and cultivate (Genesis $2: 15$, various translations). The recently emerging
COVID-19 pandemic has reinforced the function of the church in maintaining the relationship of its people with the wild animals; not eating them can prevent zoonotic transmission of animal pathogens into humans.

In this paper, we report how local churches have been involved in advising healthy consumption of animal meat, especially during the festival seasons (e.g., Christmas and New Year). This is embedded within the sermons at the discretion of the priest of the village-level congregations. More recently, on the synodal level, formal memorandums of understanding were established, including an agreement with a local pro-environment, nongovernment organization to protect wild animals, particularly the local ape (yaki, Macaca nigra) from being hunted for food. Three factors form a related triangle of notions: the church, food culture, and conservation. These will be the foci of discussion in this report.

\section{The excessive and exotic eating habit of Minahasan people during the festivals}

In Minahasa, Christmas is the most celebrated festival of the year, followed by the harvest thanksgiving period from June to August. While the 
congregations celebrate Christmas day by attending the services in the church, the feast usually continues for the following week until the new year on the $1^{\text {st }}$ of January. During this period, special foods are prepared, mostly high in fat content. The main domesticated animals to be slaughtered are pigs, chickens, ducks, followed by cows. Unfortunately, it has been a tradition that the consumption of noncattle, wild animals also increased during the festival, including dogs, bats, snakes, turtles, and even some monkey species (ref. 1 and 2 in Mandias, $2019^{5}$ ). The consumption of these exotic animals is rather cultural than nutritional, merely for celebration purposes.

The church has been advising a reduction in this practice by incorporating health advice into the sermons around the Christmas season. It is not uncommon for the priests to preach about healthy eating during the season, mostly quoting that, "our body is the temple of God, therefore we need to take care of the food intake to prevent diseases," "Christ was born into humbleness, not feast," as well as incorporating some satires about rational feastings, such as, "Don't insist to eat brenebon (=red bean meat soup, a delicacy) in December, and pay the bon (=debt) for the whole following year." Approaches, however, were mostly - if not always - persuasive, not restrictive.

It is noteworthy that Minahasa has the secondhighest prevalence of diabetes mellitus type 2 in Indonesia. ${ }^{6}$ The incidence of acute gout is also among the highest in Indonesia, which is likely to be related to the high-purine intake, including from wild and exotic animal meat. ${ }^{5}$ It is the authors' observation as practicing physicians in this area that there is an increase of acute gout incidence in January compared to other months. No randomized controlled study, however, has shown whether more aggressive contextual preaching during the festival season could reduce the incidence of acute gout or diabetes in the long term. Also, there seems to be no direct scriptural prohibition against the habit of eating wild animals. Therefore, other approaches to

July 2021. Christian Journal for Global Health 8(1) the congregation are necessary, most likely at the level of the church organizational policy.

\section{Green gospel, food culture, and}

\section{pandemic}

In 2019, the synodal board of GMIM signed an agreement with Yayasan Selamatkan Yaki (YSY, Safe Ape Foundation) to incorporate the value of ecological conservation of wild animals into the curriculum of GMIM Sunday School. The syllabus contained nine chapters about forest, fauna, marine, waste management, and others. ${ }^{7}$ While the Foundation has expertise in this conservation area, the Church leaders identified and shared the scriptures concerning the environment, e.g., Genesis 2:15 and the story of Noah's Ark. This can be considered as the initial formal agreement of the church with an external organization, mutually reaching out for a common aim of wildlife conservation. In fact, ecological themes have appeared in GMIM's vision statements and themes, most notably in 2014: “ . . . to overcome poverty, injustice, radicalism, and environmental destruction." The 2019 pact with YSY can therefore be considered a manifestation of the vision statement. Encouragement from the pulpit was also given, asking the congregation, specifically, not to consume protected wild animals during the festivals. Nevertheless, due to the novelty of the program, it might be too early to observe the effect of the agreement. The Covid-19 pandemic in the year following 2019 affected the implementation of the agenda. On the other hand, the year 2020 has added another set of reasonings for advocating wildlife animal conservation.

The SARS-Cov2 virus is believed to be originated from bats, mainly because it shares homology sequences with bat coronaviruses. ${ }^{8}$ Although an exact incidence of zoonotic transmission has not yet been established, the imminent danger of the bat-to-human transmission of coronaviruses was predicted before it emerged. ${ }^{9}$ Thus, humans need to keep away from the wild 
pathogen and, hence, to the carriers - in COVID-19 context, the bats. Many Minahasan people are proud bat-eaters. The church, therefore, in addition to actively promoting healthy lifestyle behavior through the sermons, also acts as a provider of effective social control against wild animal consumption by reflecting on the ongoing pandemic and providing authoritative advice to avoid wild animal consumption.

\section{Conclusion}

As the largest Christian church organization in Minahasa, GMIM has been actively promoting healthy eating habits, and more recently, started to embrace a commitment against wild animal consumption. However, the parameters for evaluating these commitments have not been well developed. Therefore, as the process of fulfilling the calling for ecological preservation is ongoing, it is suggested that other collaborations, perhaps with the academia or public health agencies, can be made to systematically analyze the impact of Christian ecotheology application within GMIM on the health of the planet. The green gospel should embrace the conservation of yaki, other wild animals, the environment, and the individual churches themselves as the body of Christ - the center of creation.

\section{References}

1. Ministry of Religious Affairs of North Sulawesi Indonesia. Data tempat ibadah di Sulut tahun 2019 [Internet]. Manado, Indonesia; 2019. Available from: https://sulut.kemenag.go.id/data_umat/4/DataTempat-Peribadatan-di-Sulut-Tahun-2019

Peer Reviewed: Submitted 1 April 2021, accepted 3 May 2021, published 30 July 2021

Competing Interests: None declared.

Correspondence: Alva Supit, Manado State University, Indonesia. alva.supit@unima.ac.id
2. North Sulawesi Statistic Bureau. Provinsi Sulawesi Utara dalam angka 2021 [Internet]. Manado, Indonesia; 2020. Available from: https://sulut.bps.go.id/publication/2021/02/26/ef5603f cc2c336b42cc0e4a5/provinsi-sulawesi-utara-dalamangka-2021.html

3. Weichart G. Makan dan minum bersama: feasting commensality in Minahasa, Indonesia. Anthropol food. 2001 Mar 21;S3:S3-8. https://doi.org/10.4000/aof.2212

4. Resane KT. "And they shall make you eat grass like oxen"(Daniel 4: 24): Reflections on recent practices in some new charismatic churches [Internet]. Pharos J Theol. 2017;98(1):1-17. Available from: https://www.pharosjot.com/uploads/7/1/6/3/7163688/ article $10 \quad$ vol 98 2017.pdf

5. Mandias R. The relationship between eating wild animal meat with the level of uric acid in Langowan Minahasa, Indonesia. KnE Life Sci. 2019;4(13):64-9. https://doi.org/10.18502/kls.v4i13.5226

6. Utomo H, Wungow N, Marunduh S. Kadar Hba1c pada pasien diabetes melitus tipe 2 di Puskesmas Bahu kecamatan Malalayang kota Manado. eBiomedik. 2015;3(1). https://doi.org/10.35790/ebm.3.1.2015.6620

7. Selamatkan Yaki. GMIM Church supports yaki conservation - Selamatkan Yaki [Internet]. 2019 [cited 2021 Apr 2]. Available from: https://www.selamatkanyaki.ngo/2019/06/19/1417/

8. Fang G, Song Q. Legislation advancement of one health in China in the context of the COVID-19 pandemic: from the perspective of the wild animal conservation law. One Heal. 2021;12:100195. https://doi.org/10.1016/j.onehlt.2020.100195

9. Fan Y, Zhao K, Shi Z-L, Zhou P. Bat coronaviruses in China. Viruses. 2019 Mar;11(3). https://doi.org/10.3390/v11030210 
Cite this article as: Supit A, Telew A, Bawiling N. The church, food culture, and ecotheology: an ongoing church effort to reduce bushmeat eating in Minahasa, Indonesia. Christ J Global Health. July 2021;

8(1):64-68. https://doi.org/10.15566/cjgh.v8i1.537

(C) Authors. This is an open-access article distributed under the terms of the Creative Commons Attribution License, which permits unrestricted use, distribution, and reproduction in any medium, provided the original author and source are properly cited. To view a copy of the license, visit http://creativecommons.org/licenses/by/4.0/

\section{cjgh.org}

